\title{
EKUMENICZNA DZIALALNOŚĆ ŚWIECKICH DWORZAN CESARZA JUSTYNA I (518-527) W SWIETLE ICH KORESPONDENCJI Z RZYMEM
}

Kiedy w 518 r. tron w Konstantynopolu obejmowal cesarz Justyn I zastał w państwie niezwykle skomplikowaną sytuację religijną. Bizancjum rozdarte było nie tylko pomiędzy zwalczającymi się monofizytami i katolikami, ale i zwolennikami edyktów cesarskich, które miast lagodzić istniejące napięcie, dolały tylko oliwy do ognia ${ }^{1}$. Jeden $\mathrm{z}$ takich edyktów doprowadził pod koniec $\mathrm{V}$ wieku do schizmy w Kościele, zwanej od imienia patriarchy Konstantynopola Akacjusza - akacjańską, mającą trwać ponad 30 lat. Skostniała polityka religijna cesarza Anastazego I (491-518), sprzyjająca wyraźnie monofizytom niczego nie zmieniła. Wobec takiego stanu rzeczy nowo wybrany władca podjął szczere wysiłki na rzecz położenia kresu dramatycznej sytuacji religijnej w państwie. Zdając sobie doskonale sprawę, ze nie osiągnie sukcesu na polu jedności religijnej w cesarstwie bez uwzględnienia wiodącej w tym względzie roli Stolicy Apostolskiej, nawiązał ożywione rozmowy mające przywrócić utraconą jedność z Rzymem. Znalazł przy tym pełne poparcie ze strony swych najbliższych wspólpracowników, wśród których najbardziej wyróżniali się dwaj: Witalian i Justynian. Pierwszy z nich jeszcze podczas rządów cesarza Anastazego okazal się zdecydowanym obrońcą katolickiej wiary w szacie chalcedońskiej. Potrafił nawet kilkakrotnie zagrozić władcy wzniecając w latach 513-515 rewoltę w prowincjach naddunajskich cesarstwa po hasłem obrony Chalcedonu. Po wstąpieniu na tron cesarz Justyn (518-527) znalazł w nim gorącego zwolennika przywrócenia kościelnej jedności i umiejętnie wykorzystał jego bliskie relacje $z$ Rzymem. Niezwykle popularny wśród ludności Konstantynopola, został najpierw Witalian dowódcą gwardii pałacowej z tytułem patrycjusza, a potem w $520 \mathrm{r}$. otrzymał konsulat. Oprócz dążenia do pojednania $z$ Rzymem wspieral cesarza $z$ własnej inicjatywy w dążeniach do przywrócenia

${ }^{1}$ Zob. F. Hofmann, Der Kampf der Päpste um Konzil und Dogma von Chalkedon von Leo dem Großen bis Hormisdas (451-519), w: A. Grillmeier - H. Bacht, Das Konzil von Chalkedon, II, Würzburg 1953, 13-94. 
w całym imperium zasad Chalcedonu ${ }^{2}$. Wespół $z$ Witalianem rozwinął na szeroką skalę politykę jedności religijnej w całym cesarstwie wschodnim siostrzeniec cesarza Justynian. To on stał za wszelkimi posunięciami władcy, mającymi przynieść zgodę religijną. Poza tym miał też Justynian dalekosiężne plany; pragnął dać odpór barbarzyńskim ludom, które w znacznej swej masie były ariańskie oraz chciał przywrócić panowanie Bizancjum nad utraconą w $\mathrm{V}$ wieku zachodnią częścią imperium. I on rozumiał przy tym doskonale, że nie da się tego osiągnąć bez pojednania ze Stolicą Apostolską. Wspierany przez tak wybitne osobistości, skierowal cesarz do bezpośrednich rozmów zjednoczeniowych z Rzymem dwóch wysokich urzędników: Aleksandra (vir spectabilis) ${ }^{3}$ i przyjaciela Justyniana Gratusa (comes sacri consistorii) ${ }^{4}$. Ci dwaj świeccy dostojnicy mieli zabiegać w Rzymie o to, by papież Hormizdas dołożył wszelkich starań odnośnie pojednania. Gratus swoją umiejętnością prowadzenia trudnych rozmów zyskal sobie w Rzymie uznanie i zaufanie. Kilkakrotnie papież w swojej korespondencji wspomina o nim z prawdziwą estymą, okazując szczere zatroskanie, gdy losy Gratusa ulegną powikłaniu ${ }^{5}$. Wiele zależało od ludzi dworu należących do najbliższego otoczenia basileusa. Oni tworzyli w jakimś stopniu atmosferę sprzyjającą wysiłkom zjednoczeniowym wladcy, i co ważne, sami je podejmowali. $Z$ zachowanej korespondencji widać wyraźnie, że czynili to szczerze z przekonaniem o słuszności sprawy.

Żeby zadośćuczynić etykiecie, pierwsze miejsce w korowodzie dworskim zajmuje współmałżonka Justyna, cesarzowa Eufemia. Z przekonania zwolenniczka Chalcedonu i rzeczniczka pojednania $z$ Rzymem, energicznie wspierała męża w jego wysiłkach okolo przywrócenia jedności w Kościele. Nic więc dziwnego, że w jednym $\mathrm{z}$ listów papież prosi ją, by zachęcała Justyna do wytrwałości w powziętym dziele 6 . I rzeczywiście, wysiłki cesarzowej musiały być skuteczne, skoro już po przywróceniu jedności, raz jeszcze papież zwrócił

${ }^{2}$ Specyficznie wyglądał jego stosunek do przywódcy monofizytów Sewera z Antiochii. Oburzony na jego wybryki, zażądał Witalian ni mniej ni więcej, tylko obcięcia mu języka i natychmiast prefekt pretorium Wschodu Ireneusz otrzymal rozkaz ujęcia Sewera, por. Marcellinus Comes, Chronica, MGHaa 11, 101.

${ }^{3}$ Por. Epistulae imperatorum Pontificum et aliorum (ann. 367-553), nr 142, ed. O. Guenther, Collectio Avellana, CSEL 35, 587 (dalej: Coll. Avell).

${ }^{4}$ Por. Gesta Pontificum Romanorum, MGH SS, ed. Th. Mommsen, cz. 1, München 1982, 128 : „Sumpsit itaque imperium Justinus orthodoxus et dixerit auctoritatem suam ad papam Hormisdam sedis apostolicae Gratum et inlustrem nomine, sperans a sedem apostolicam, ut reintegraretur pax ecclesiam".

${ }^{5}$ Coll. Avell. nr 178, CSEL 35, 634: „Per quam nobilitatem tuam honorifice salutamus postulantes, ut sollicitudinem nostram de bono vestrae prosperitatis non desinatis efficere certio. rem, quia incolomitatis vestrae bona quibuslibet indiciis Deo nostro cupimus propitiante cognoscere.

${ }^{6}$ Coll. Avell. nr 156, CSEL 35, 604: „Hinc est, quod quia sanctum coniugii vestri constat esse propositum, has fiducialiter ad vestram clementiam litteras destinamus, utper vos ad perficiendam ecclesiae pacem mariti vestry pietas amplius incitetur". 
się do niej z prośbą, by wpłynęła na cesarza w sprawie powrotu do swoich biskupich stolic pasterzy wygnanych za swą wierność Chalcedonowi?

Przejdźmy teraz do kolejnych osób $\mathrm{z}$ dworu cesarskiego. By nie uchybić pierwszeństwu należnemu damom, im poświęcimy teraz nieco uwagi. Zwolenniczkami pojednania z Rzymem, które wiele zdziałały na rzecz jedności w oparciu o Chalcedon byly: Anastazja - żona Pompejusza, bratanka cesarza Anastazego oraz Palmacja. One zostały obdarowane listami papieskimi, w których nadawca wzywa dostojne adresatki, by w sprawie jedności postępowały zgodnie ze swoimi przekonaniami i z calego serca poparły jego wysiłki zmierzające do tego, by cała społeczność chrześcijańska wyznawała prawdziwą wiarę ${ }^{8}$. Na szczególne potraktowanie zasługuje jeszcze jedna dama dworu Juliana Anicja. Wywodząc się z zachodniej części cesarstwa, miała parantele naprawdę nie byle jakie: wnuczka Walentyniana III, córka cesarza Zachodu Olibriusza i Placydii Młodszej, poślubioną została Areobindusowi pełniącemu w Bizancjum funkcję magister militum per Orientem. Będąc na bizantyjskim dworze jeszcze za panowania Anastazego I, wbrew jego polityce religijnej, zabiegała wespół z Anastazją i Pompejuszem o zwycięstwo uchwał chalcedońskich $w$ całym imperium ${ }^{9}$. Z jej strony zatem należało spodziewać się zdecydowanego wsparcia negocjacji zjednoczeniowych. I tak w istocie było.

Teraz przejdźmy do dwóch dostojników cesarskich Patrycjusza i Celera, zwlaszcza, że ten ostatni brał udział w pryzgotowaniu wstąpienia Justyna na tron. W obu tych mężach, zarówno cesarz jak i papież mieli silne wsparcie w dziele przywracania jedności. Pisał o niej z powagą Hormizdas, że:

„,...tego rodzaju rzecz godna jest poparcia i pomocy synów Kościoła. Przeto $\mathrm{z}$ należną czcią pozdrawiając was, prosimy o poparcie u cesarza sprawy moich legatów. Trud waszych Wysokości znajdzie niebieską nagrodę, a my Wszechmogącemu Bogu złożymy dzięki za wasze wstawiennictwo"10.

Ta przytoczona pokrótce korespondencja, płynąca ze strony Rzymu jako odpowiedź na inicjatywę Justyna, miała swoje uzasadnienie w tym, że Hormizdas

${ }^{7}$ Coll. Avell. nr 203, CSEL 35, 662: „Quaesumus namque, ut tandem de venerabilibus fratribus et coepiscopis nostris Helia Thomate atque Nicostrato, quod sacrissimorum canonum dictat auctoritas, vobis decernentibus impleatur, ne videantur ut auctores alicuius mali, quod primi ad unitatem sedis apostolicae festinarunt, in communi omnium gaudio soli meruisse percelli et in facto laudabili victam personali odio cessise iustitiam. Nostris ergo precibus apud clementissimum Augustum vestras adiungite, ut fructum, quem illis patrum regulae tribui et conservari praecipiunt, inimica tergiversatio auferre non posit".

${ }^{8}$ Coll. Avell. nr 157, CSEL 35, 605: „quatenus cum repulsis remotisque his, quos apostolicae sedis damnavit auctoritas, ad unam, quae recta est, communionem plebs Christiana sedierit, beatum Petrum apostolum, pro cuius fide nitimur, in vestris habere possitis actibus adiutorem".

${ }^{9}$ Por. E. Schwartz, Publizistiche Sammlungen zum Acacianischen Schisma, w: Abhandlungen der Bayer. Akademie der Wissenschaften, Phil. His. Abteilung, Neue Folge, Heft10, München 1934, s. 245 .

${ }^{10}$ Coll. Avell. nr 152, CSEL 35, 600. 
zdawal sobie sprawę $\mathrm{z}$ tego, jak wiele dobrego około pojednania mogą uczynić świeccy dworzanie, zwlaszcza tacy, co do których legaci papiescy donosili, że są oddani sprawie jedności i zgody w Kościele. Było to więc mistrzowskie pociągnięcie z jego strony, iż szukał poparcia tych wpływowych osobistości. Kryła się za tym znajomość poczynań św. Cyryla Aleksandryjskiego, który podobnie urabiał dwór cesarski w kwestii potępienia Nestoriusza. Mógł też papież znać zasługi dworu w Rawennie, a zwłaszcza Galii Placydii odnośnie potwierdzenia wyboru na Stolicę Piotrową papieża Bonifacego, przy równoczesnym utrąceniu uzurpatora Eulaliusza na początku V wieku. I tym razem było podobnie. Dwór cesarski poczynił wiele dla osiągnięcia jedności między Wschodem i Zachodem, czego ukoronowaniem było podpisanie papieskiej formuły wiary i obchodzenie w pełnej jedności Świąt Wielkanocnych 519 roku. Z obfitej korespondencji, jaka napłynęła do Rzymu po wspomnianym wyżej fakcie ze strony dworzan, wynika jedno: osiągnięta jedność byla wysiłkiem solidarnych zabiegów wszystkich, co szczerze podjęli trud zapewnienia jej zwycięstwa. Pięknie o tym pisze bratanek Anastazego Pompejusz:

„....za sprawą waszych, Ojcze, modłów, dzięki pobożnym zasługom cezara i nas synów twoich, złączonych duchową miłością, których zawsze solidaryzowala troska o jedność [...] został osiągnięty pokój w Kościele"11.

Juliana Anicja i Anastazja, jak przystało na rasowe damy dworu, skromnie ukrywają swoje zasługi, przypisując sukces Hormizdasowi, ale pod prosbą, by papież nie odwoływał swoich legatów $z$ Konstantynopola zbyt szybko okazują, jak są wytrawnymi znawczyniami sytuacji. Są przekonane, że niepotrzebny pośpiech mógłby zniweczyć również ich trud ${ }^{12}$. Papież docenil tę słuszną sugestię i nie tylko nie odwołał legacji, ale poprosił o dalsze poparcie ze strony dworzan. Anastazja ${ }^{13}$, Juliana Anicja ${ }^{14}$, Pompejusz ${ }^{15}$ i German ${ }^{16}$, bratanek Justyniana, otrzymali papieską korespondencję. Papież pisał do Juliany Anicji:

„Tak jak waszą osobę uszlachetnia królewska krew, tak niech błyszczy światło pobożnych zasług. Stąd też pozdrawiając Was z należną czcią, pragniemy, abyście trwali w dotychczasowym nastawieniu i dokładali starań do szczęśliwego zakoń-

${ }^{11}$ Coll. Avell. nr 163, CSEL 35, 615.

12 Coll. Avell. nr 164, CSEL 35, 615: „Quapropter stilo venerationis alloquentes sanctitatem vestram admonemus, ut intimetis destinatis a vobis reverentissimis viris nullo modo abscedere, antequam, sicut pervideritis, ut oportet, firmentur ea, quae bene disposita sunt ab eis, ut amputatis omnibus reliquiis transiti erroris impendiis vestrae beatitudinis roborata unitas ad effectum perpetuum deducatur".

13 Coll. Avell. nr 180, CSEL 35, 635.

14 Coll. Avell. nr 179, CSEL 35, 635.

15 Coll. Avell. nr 174, CSEL 35, 630.

${ }^{16}$ Coll. Avell. nr 211, CSEL 35, 669. 
czenia tak ważnej sprawy. Oby nie pozostał na przyszłość żaden zarodek zła, przez co mógłby odżýc na nowo przy byle okazji wróg świętej wiary"17.

Podobną treść, z podkreśleniem zasług adresatów i prośbą o dalsze wysiłki w utrzymaniu jedności, zawierają pozostałe listy.

W 520 r. papież otrzymal od jednego $\mathrm{z}$ dworzan - Celera list, $\mathrm{z}$ którego wynika, że na Wschodzie istniała świadomość, iż prawdziwą jedność można zbudować w oparciu o uznanie prymatu Stolicy Apostolskiej w Kościele. Po opisaniu wysiłków podjętych przez dwór na rzecz jedności, Celer informuje, kto stoi na straży jej nieskazitelności. Oto jego słowa:

„Przedtem cale Ciało chorowało, teraz zaś, gdy głowa Kościoła, którą i Wschód uważal za jedyną, zastosowała lekarstwo, nastała jedność. Pogrzebano rozłam i inna niemała część Kościoła, dzięki łasce Bożej, uległa oczyszczeniu i zjednoczeniu. Wszyscy teraz żywimy nadzieję, że łaska Boża, zawsze użyczana Stolicy Apostolskiej, takiego udzieli nam Bożego natchnienia, że przez waszą dobroć i wyrozumiałość także i te członki Kościoła, które są chore, na nowo przyjąwszy waszą zbawienną moc, połączą się"18.

W tym pobieżnym przedstawieniu korespondencji między Rzymem i cesarskim dworem Justyna zabrakło tej, jaką prowadził siostrzeniec cesarza Justynian. Powód jest jasny: jej obfitość, głęboka treść teologiczna, z której słynął Justynian, wreszcie sama jego postać wymagają osobnego potraktowania. Przedstawiona poniżej korespondencja pomiędzy nim a papieżem Hormizdasem, stanowi tylko niewielki fragment dotyczący bezpośrednich przygotowań pod dzieło pojednania z 519 roku. Wymianę listów rozpoczął Justynian pismem świadczącym o jego doskonałej orientacji w problemie, a zatem musiał dogłębnie przestudiować $\mathrm{w}$ archiwum całą poprzednią papieską korespondencję $e^{19}$. W owym zaś liście, wiezionym do Rzymu przez Gratusa, oświadcza Justynian, iż sytuacja w Kościele Wschodnim jest taka, że ze strony papieża trzeba tylko przysłowiowego postawienia kropki nad „i”, bądź w postaci osobistego jego przybycia do Konstantynopola, bądź też wysłania legacji ${ }^{20}$.Ten zdecydowany ton znanionuje już późniejszy autokratyzm Justyniana, gdy zasiądzie w 527 r. na tronie cesarskim. Nie zachowała się odpowiedź papieska na list. Być może została ona wysłana, lecz zaginęła, ale możliwe jest też i to, że papież

${ }^{17}$ Coll. Avell. nr 179, CSEL 35, 635.

${ }^{18}$ Coll. Avell. nr 179, CSEL 35, 657, por. List Anastazji, Coll. Avell. nr 165, CSEL 35, 616.

19 Por. W. Haacke, Die Glaubensformel des Papstes Hormisdas im Acacianischen Schisma, Roma 1939, s. 78.

20 Por. Coll. Avell. nr 147, CSEL 35, 593: ,...sed absque quadam dilatatione vestrum expectamus adventum, quem si qua tarditas. Quod fieri non debet forsitan retinuerit, interim vel sacerdotes idoneos destinare festinet, quia totus mundus partium nostrarum conversus ad unitatem moras non patitur...". 
unikając dyplomatycznie odpowiedzi, dał do myślenia Justynianowi co do sposobu prowadzenia rozmów ${ }^{21}$. Dopiero wysłana papieska legacja wiozła ze sobą krótki list dla Justyniana, w którym papież nie nawiązuje żadnym słowem do osobistych zaprosin go do Konstantynopola. Zachęca tylko czcigodnego adresata, by kroczył pewną drogą pokoju ${ }^{22}$. Justynian stanął na wysokości zadania. Gdy tylko legaci papiescy znaleźli się blisko Konstantynopola, zostali niezwykle uroczyście powitani przez najwyższych dostojników cesarstwa, na których czele stał sam cesarski siostrzeniec. On też najwięcej dokonal na rzecz przywrócenia pełnej zgody w trakcie bezpośrednich rozmów zjednoczeniowych, zakończonych przyjęciem papieskiej „formuły wiary” przez patriarchę Konstantynopola Jana. O tym sukcesie informowal papieża w krótkim liście sam Justynian ${ }^{23}$. Prosił też papież, by cesarski siostrzeniec wytrwał w swojej postawie:

„Mocą tej wiary, która was znamionuje, zapobiegajcie wszelkim zamachom przeciwko chrześcijańskiej wierze [...]. Wy, którzy daliście początek pokojowi katolickiego Kościoła, dalej strzeżcie tego dziela, a nie braknie wam przychylności Zbawiciela w dopełnianiu sprawy, której rozpoczęcia zainicjowało w was Boże natchnienie" 24 .

Mógł więc Hormizdas dać upust swojej radości i w odpowiedzi wyraża przekonanie, że jedność była bez wątpienia także zasługą Justyniana ${ }^{25}$. Po tym krótkim przytoczeniu fragmentu korespondencji Justyniana i Hormizdasa powróćmy do głównego wątku. Chcę powiedzieć, że jako historyk, który para się starożytnością mam prawo w podsumowaniu zarówno do oceny postawy bohaterów niniejszego artykułu, jak i do jej zaktualizowania, bo tylko wtedy historia jest żywa. Byli to ludzie, którzy o tym, czy nawa państwowa plynie we właściwym kierunku, decydowali w sposób odpowiedzialny. Uwzględniali przy tym rzecz najistotniejszą: obecność wiary i jej decydujące znaczenie w życiu publicznym. Mogą więc stanowić jakiś wzorzec dla obecnych kierowników życia politycznego. Rzecz w tym, że nam współcześni bardziej przypominają przypadkowych ludzi z zatłoczonych dworców, co tylko czekają, by pierwszemu zająć miejsce przed innymi, niż rasowych mężów stanu $z$ dworów wladców, uprawiających $\mathrm{z}$ finezją politykę uwzględniającą również religię, czujących się jak ryba w wodzie, gdy idzie o sprawy wiary, wreszcie świadomych swej od-

${ }^{21}$ Por. A.A. Vasiliev, Justin the First. An Introduction to the Epoch of Justinian the Great, Dumbarton Oaks Studies 1, Cambridge Mass. 1950, s. 169.

${ }^{22}$ Por. Coll. Avell. nr 148, CSEL 35, 594: „Non est quod se dubietas inserat; non est quod aliquid ambiguitatis accedat, cum testemini, quod et nos quidem bene novimus, accedere ad ecclesiarum concordiam religiosi principis vota...".

${ }^{23}$ Por. Coll. Avell. nr 162, CSEL 35, 614.

24 Coll. Avell. nr 176, CSEL 35, 633-634.

25 Por. Coll. Avell. nr 176 i 177, CSEL 35, 633-634. 
powiedzialności za Kościół. Pod tym względem przewyższają też wielu współczesnych nam duchownych, którzy zdają się zapominać, że frymarczenie Kościołem - żywą szatą Chrystusa, nie przystoi nawet za cenę zadowolenia mówiąc językiem papieża Hormizdasa - „bezbożnych psów”, które usiłują rozrywać ową dzianą przez samego Zbawiciela niepodzielną szatę ${ }^{26}$.

Pozostaje jeszcze jedna kwestia do rozstrzygnięcia: wobec przedstawionego tematu można sformułować zarzut, że termin „ekumeniczna działalność” użyty w tytule, jest niezgodny $z$ tym, co my zazwyczaj rozumiemy pod tym pojęciem. Trzeba zatem znaleźć winowajcę takiego brzmienia tytułu. W przeciwieństwie do rządzących, których wina pozostaje, zazwyczaj bezimienna i bezosobowa, tutaj winowajców jest przynajmniej dwóch: ks. prof. Stanisław Longosz, który takie brzmienie (ekumeniczna działalność) zaproponował i ks. Stanisław Koczwara, który to zaakceptował. Po zapoznaniu się jednak z definicją ekumenizmu, która powiada, że - co do chronologii - jest to zrodzony w XIX wieku ruch na rzecz jedności chrześcijan, zawierający pewne elementy, które towarzyszą dziejom chrześcijaństwa od czasów apostolskich, a co do celu, że jest nim prawda i jedność ${ }^{27}$, możemy bezspornie wykazać, iż w pierwszym ćwierćwieczu $\mathrm{V}$ stulecia, na dworze bizantyjskim była obecna i prawda o rozłamie w postaci schizmy akacjańskiej i szczere wysilki na rzecz jej przezwyciężenia, a ponadto troska o to, by jedność wiary pozostała nieskażoną. A zatem i dworzanom Justyna I, którzy te elementy uwzględnili, i tym, co ich wysiłki na rzecz jedności z Rzymem „ekumenicznymi” określili, należy przyznać rację.

\author{
ECUMENICAL ACTIVITY OF LAY COURTIERS \\ OF THE EMPEROR JUSTIN I (518-527), \\ ACCORDING TO THEIR CORRESPONDENCE WITH ROMA
}

(Summary)

Taking over the throne in 518 by the Emperor Justin I impacted on the emperor's court to change politics in order to support of the Chalcedonian Synod. The most important thing was that, the Emperor as well as his supporting courtiers, took into consideration the main role of the Apostolic See in protecting truth religion. Courtly guardians of Chalcedon such as the Empress Eufemia, Justinian's relative a commander of the Court Guard Vitalian, maids of honour: Anastasia, Palmacja Julianan Anicia, Celer, Pompeius, German were successful in making an ecumenical effort to restore the union in the Catholic Church.

\footnotetext{
${ }^{26}$ Por. Coll. Avell. nr 112, CSEL 35, 506.

${ }^{27}$ Por. W. Hanc - S. Napiórkowski - W. Hryniewicz, Ekumenizm, EK IV 853-863.
} 